\title{
A Novel Process for Production of Calophyllum Inophyllum Biodiesel with Electromagnetic Induction
}

\author{
Sri Kurniati ${ }^{1}$, Sudjito Soeparman ${ }^{2}$, Sudarminto Setyo Yuwono ${ }^{3}$, Lukman Hakim ${ }^{4}$ and \\ Sudirman Syam $1, *$ (I) \\ 1 Electrical Engineering Department, Science and Engineering Faculty, University of Nusa Cendana, \\ Kupang 85228, Indonesia; sri_kurniati@staf.undana.ac.id \\ 2 Mechanical Engineering Department, Engineering Faculty, Brawijaya University, Malang 65145, Indonesia; \\ sudjitospn@yahoo.com \\ 3 Department of Agricultural Product Technology, Faculty of Agricultural Technology, Brawijaya University, \\ Malang 65145, Indonesia; ssyuwono2004@yahoo.com \\ 4 Department of Chemistry, Engineering of Natural Sciences, Brawijaya University, Malang 65145, Indonesia; \\ lukman.chemist@ub.ac.id \\ * Correspondence: sudirman_s@staf.undana.ac.id; Tel.: +62-813-4264-6234
}

Received: 9 December 2018; Accepted: 17 January 2019; Published: 25 January 2019

\begin{abstract}
A novel method as proposed in the production of Calophyllum inophyllum biodiesel has been investigated experimentally. This study reports the results of biodiesel processing with electromagnetic induction technology. The applied method is aimed to compare the results of Calophyllum inophyllum biodiesel processing among conventional, microwave and electromagnetic induction. The degumming, transesterification, and esterification process of the 3 methods are measured by stopwatch to obtain time comparison data. Characteristics of viscosity, density, and fatty acid metil ester (FAME) are obtained from testing of a Gas Chromatography-mass Spectrometry (GCMS) at the Integrated Research and Testing Laboratory, Gadjah Mada University, Yogyakarta. The results present that the biodiesel produced by this method satisfies the biodiesel standards and their characteristics are better than the biodiesel produced by conventional and microwave methods. The electromagnetic induction method also offers a fast and easy route to produce biodiesel with the advantage of increasing the reaction rate and improving the separation process compared to other methods. This advanced technology has the potential to significantly increase biodiesel production with considerable potential to reduce production time and costs.
\end{abstract}

Keywords: renewable energy; microwave; free fatty acid; crude oil

\section{Introduction}

In the past two decades, the energy crisis has encouraged the development of alternative energy by seeking renewable energy resources. Alternative energy sources such as biodiesel have been developed to replace diesel or fuel oil. Generally, biodiesel is a liquid fuel processed from different sources such as palm oil [1-4], soybean oil [5-10], jatropha [11-18], cottonseed oil [19-25], soursop seed oil [26], recycled cooking oils [27-30], animal fats [31-35], and other potential triacylglycerol-containing feed-stocks [36]. Vegetable oils are mainly composed of triglycerides $(98 \%)$ and a small proportion of diglycerides [37]. Biodiesel is a mixture of fatty acid alkyl esters obtained by treating triglycerides with methanol or ethanol [38,39].

One of the potential biodiesel plants is Calophyllum inophyllum or Nyamplung in Indonesia language. The benefits of Calophyllum inophyllum as biofuel are: having a higher yield than other crops (jatropha 40-60\%, palm kernel 46-54\%, and Calophyllum inophyllum (40-74\%), and not having a chance 
to compete with food interests [40]. In addition, the productivity of Calophyllum inophyllum seeds of 20 tons/ha/year is higher than jatropha (5 tons/ha/year), and palm (6 ton/ha/year) [41]. Calophyllum inophyllum has a very high oil of $75 \%$ with an unsaturated fatty acid content of about $71 \%$ [42]. It is processed or pressed in the form of yellowish-greenish oil, similar to olive oil, which is aromatic and tasteless. It usually produces fruit twice a year around $100 \mathrm{~kg}$ in weight and with an oil content of about $18 \mathrm{~kg}$ [43]. Calophyllum inophyllum oil has a higher viscosity, but the capillary ability is lower than kerosene. Calophyllum inophyllum oil yields are forged or pressed between $40-70 \%$ of the dry seed mass [44], and the degumming process is $62.80-65.89 \%$ [45].

Generally, biodiesel is processed by thermal or heating system. Biodiesel processing with conventional heating systems is the most widely employed method. The conventional biodiesel processes are based on the use of high-power heating and magnetic stirring. Biodiesel processing is initiated with the process of dry seed pressing into Crude Calophyllum Oil (CCO). Through the degumming process, Refined Crude Calophyllum Oil (RCCO) is obtained, as followed by the esterification process. The next transesterification process is performed to produce Crude Biodiesel and, finally, biodiesel is obtained through washing and drying.

Due to the existence of several stages in the processing of biodiesel causing high cost of biodiesel production, the implementation of the production process is operationally inefficient. Such inefficiencies are marked from a degumming process which is heated at a temperature of $80^{\circ} \mathrm{C}$ for $30 \mathrm{~min}$, until the sediment appears, and an esterification process lasting for $1-2 \mathrm{~h}$ at temperature $60{ }^{\circ} \mathrm{C}$ and transesterification process lasting for $1 \mathrm{~h}$ at temperature $30-65{ }^{\circ} \mathrm{C}$. In [46] describes, conventional biodiesel production is generally conducted at high temperatures with external heat sources. The heat transfer is considered less effective as it occurs as a conduction and convection system. In addition, conventional heating such as hotplate takes a long time and consumes high power. However, although, [47] has improved it by using a homogenizer system for transesterification reactions, the research has been only able to reduce the reaction time by $30 \mathrm{~min}$ (half of $60 \mathrm{~min}$ ).

To address the challenge of high production cost, several efforts have been pursued to optimize the biodiesel production process. Microwave technology, has been selected as an alternative method with several advantages due to its quality issue [48,49], energy efficiency [50], and environmental impact [51,52]. The other technologies are less likely to be conducted as they produce more heats from the material and are not transferred from the outside materials as expected. The heating may also be selective, depending on the dielectric properties of the material. Moreover, microwave technology is preferred as it can propagate through the liquid by the more efficient heating process on the production of biodiesel, consuming a shorter time [50,53-55].

Regarding the processing biodiesel, a new method of electromagnetic induction heating is proposed by the researchers. Induction heating technology has been widely applied to the manufacture of induction cookers and is able to provide faster heat than the microwave. The induction heater (IH) is an alternating electrical current from the power unit flowing through a coil made of copper. This current will cause an electromagnetic field of varying magnitude. This field will generate an electric current on the inside metal material. This electric current is known as eddy current which generates heat to melt the metal.

\section{Basic Principle}

Induction heating is the process of heating objects that are electrically carried out (normally metal) with electromagnetic induction, where eddy currents are produced in the metal and the resistance leads to metal Joule heating.

The basic theory of electromagnetic-induction, however, is similar to a transformer. The transformer works due to the phenomenon of electromagnetic induction, when there is a current flowing in a closed circuit, it will produce various electromagnetic fields. As with transformers, electromagnetic fields (in primary coils) which affect secondary coils and secondary coils produce induced radiation and AC current flows (if the secondary coil is a closed circuit). An induction heater 
(IH) consists of three primary elements of electromagnetic-induction, skin effects, and heat-transfer [56]. Figure 1 displays the basic principle of induction heating, contain inductive-heating coils and current and illustrates electromagnetic-induction and skin-effects. Figure 1a indicates the simple structure of a transformer, where the secondary-current is in direct proportion to the main current in accordance with the turn-ratio.

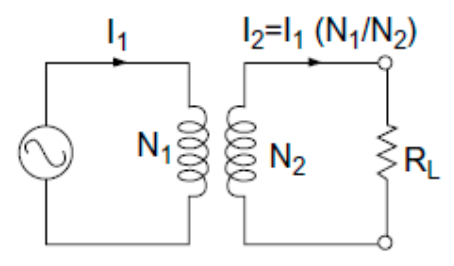

(a)

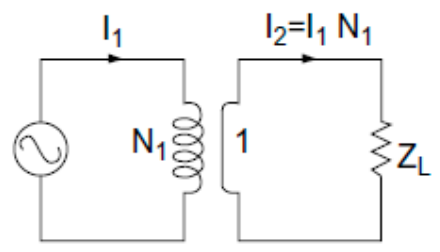

(b)

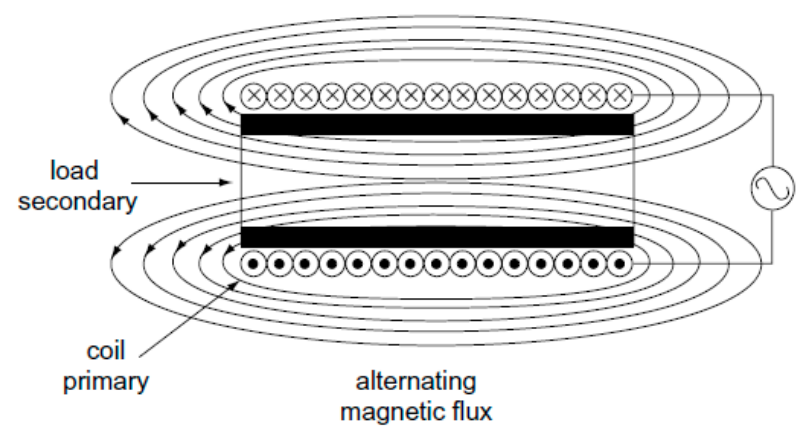

(c)

Figure 1. Basic induction: (a) equivalent-circuit of transformer; (b) secondary transformer of short circuit; (c) concept of induction heating.

When the secondary-coil is once turned on short-circuited, a major heat loss occurs to increase the secondary current (load-current), as shown in Figure 1b. The amount of current in the secondary coil $\left(\mathrm{I}_{2}\right)$ is determined from the magnitude of the current on the primary coil $\left(\mathrm{I}_{1}\right)$ and from the ratio of the windings between the primary and secondary coils $\left(\mathrm{N}_{1} / \mathrm{N}_{2}\right)$. In this figure, when the secondary coil is replaced with 1 wire $\left(\mathrm{N}_{2}=1\right)$ and is made into a closed circuit, a large coherent ratio value of the primary and secondary coils is obtained causing a large secondary current $\left(\mathrm{I}_{2}\right)$.

This process will also be followed by a substantial increase in heat due to an increase in the load. The concept of induction heaters where energy is supplied from the same source of a combined number of primary and secondary losses is presented in Figure 1c. In this figure, the primary inductive windings have many turns, while the secondary windings are only one and are short-circuited. In IH design, it takes the maximum heat energy generated by the secondary windings, where the gap of the inductive heating coil is designed as small as possible and secondary is made with low-resistance and high-permeability. Nonferrous metals weaken energy efficiency due to their high resistance and low permeability.

\subsection{Electromagnetic Induction}

The output of IH flows an alternating current (AC) to supply an electric coil (induction-coil). The induction coil becomes a source of heat inducing an electric current to a work-piece or to a metal section to be heated. In addition, the induction coil as a heat source has no contact with the work-piece, and heat only occurs in the local area, especially in the zone inside the coil. This occurs because the presence of AC in the induction coil has an invisible electromagnetic force field (flux) around. When the work-piece is placed inside the induction-coil, the force lines concentrate in the air gap between the coil and the work-piece. The induction-coil functions as the major transformer with the work-piece to be heated into a secondary transformer. As a result, the force field in the induction coil causes the 
similar and opposite electric current in the work-piece. Further, the work-piece heats up due to the current flow resistance of the induced electric current. The level of heating of the work-piece is affected by the induction of current frequency and current intensity, material specific heat, material magnetic permeability, as well as by material resistance to current flow.

Based on Figure 1, when the AC current enters the coil, the magnetic-field is formed around the coil, according to Ampere Law as calculated in the following Equation (1):

$$
\begin{gathered}
\int H d i=N i=f \\
\varnothing=\mu H A
\end{gathered}
$$

This formula states that: when the object is inserted into a magnetic field, they will cause changes in the velocity of magnetic motion.

The density of the magnetic field decreases as the object reaches close to the center of the surface. Faraday's Law states that the electric current produced on the surface of a conductive object has an inverse relationship with the current in an inductive-circuit as depicted in Equation (2).

$$
E \frac{d \lambda}{d t}=\frac{d \varnothing}{d t}
$$

Equation (3) describes an electrical energy caused by induced currents and eddy currents which changed into heat energy.

$$
P=\frac{E^{2}}{R}=i^{2} R
$$

where,

$$
\begin{aligned}
& R=\text { Resistance is determined by resistivity }(\rho) \text { and permeability }(\mu) \text { of conductive objects } \\
& i=\text { Current is determined by the magnetic of field intensity. } \\
& E=\text { Induction voltage } \\
& P=\text { Power }
\end{aligned}
$$

\subsection{Eddy Current}

Induction heating arises when an electric current or eddy current is induced into the work-piece under conditions of poor electrical conductors. To produce the induction heating to be efficient and practical, the specific relationship between the frequency of an electromagnetic field that produces an eddy-current, and the properties of a work-piece, must be satisfied. The basis of induction heating is eddy currents which are produced outside the work-piece or commonly called as "skin effect" heating. The level of induction heating depends on the high frequency of the electric current, electrical resistance, and relative magnetic-permeability of the work-piece.

Eddy Current is the induction of alternating electric current in a conductive material by an alternating magnetic-field (as generated by alternating electric-current). The induced current inside the modified material causes a change in the value of the induced current through the material. The eddy current principle is based on Faraday's law which states that when a conductor is cut out the force lines of the magnetic field or electromotive force (EMF), it will be induced into the conductor. The amount of EMF depends on: (1) size, strength, and magnetic field density; (2) the speed at which the magnetic force lines are cut; and (3) quality of conductors. Since eddy current is an electric current in the conductor, it will also produce magnetic field. Lenz's law states that the magnetic field of the induced current has a direction opposite to the cause of the induced current. The magnetic field of eddy current is in opposite direction to the magnetic field of the coil as demonstrated in Figure 2. 


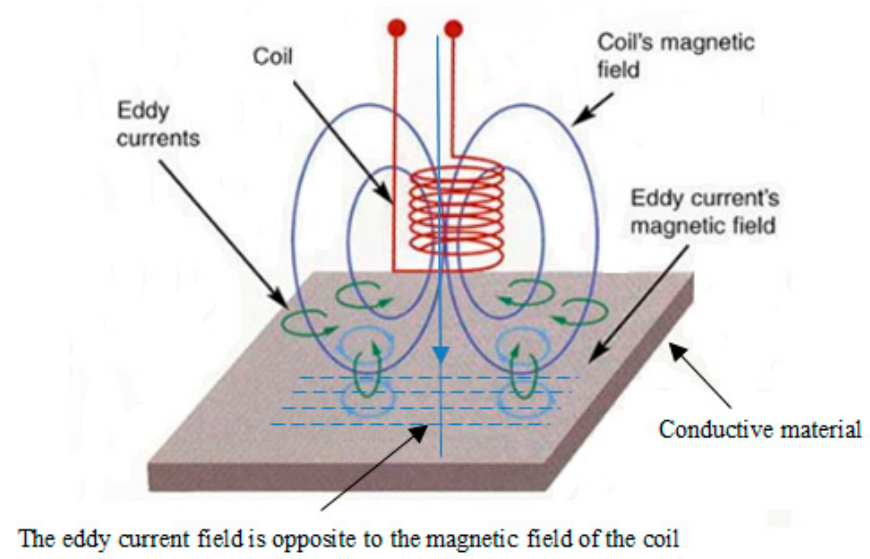

Figure 2. Direction of magnetic field.

\subsection{Operating Fundamental of an $\mathrm{IH}$}

A block diagram of IH is shown in Figure 3. A high-frequency AC voltage is generated from the power module. Convert the AC current coming from the power source to DC using a rectifier. Then, connect this DC current to a high-frequency switching circuit to administer high-frequency current to the heating coil. This high frequency AC power is sent to the coil to cause flux, the size of the generated flux depends on the area of the induction coil used. This is because the induction heater utilizes losses that occur in the inducing coil. According to Ampere's Law, a high-frequency magnetic field is created around the heated coil. Eddy currents play a dominant role in the induction heating process, the heat generated in the material depends on the size of the eddy current induced by inducing windings. When the coil is flowed by AC, it creates a magnetic field around the conductive wire. The magnitude of the field changes according to the current flowing in the coil.

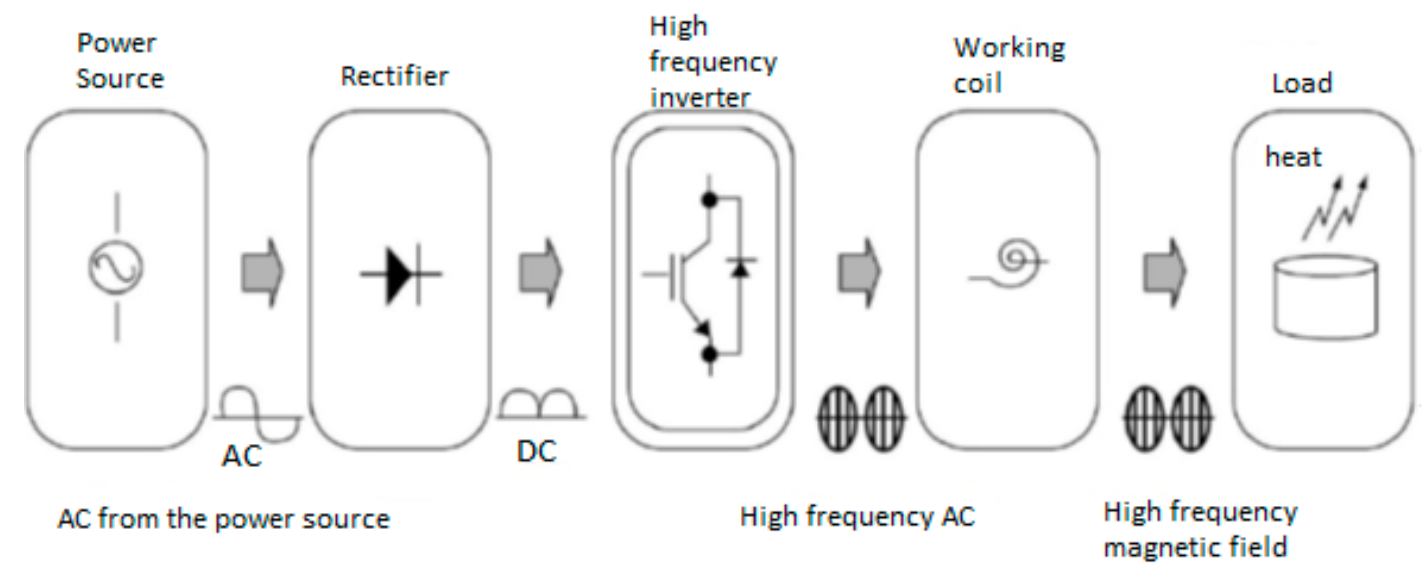

Figure 3. Block diagram of an induction heater.

\section{Topology of IH}

\subsection{Power System of $I H$}

Currently, IH becomes a popular heating technology which has been developed in industrial, domestic and medical applications, having advantages such as efficiency factor, fast-heating, safety, cleanliness and accurate control [57]. Since the discovery of semiconductor technology, the second major revolution of $\mathrm{IH}$ technology is developed. The use of high-power semiconductor devices and high-frequency power supply application has performed great progress. Among them are silicon-controlled rectifiers (SCR), and gate turn-off thyristor which have been widely utilized to implement a reliable power converter. The expansion of high-frequency power electronics for IH 
requires the metal-oxide-semiconductor field-effects (MOSFETs) and bipolar-junction-transistors (BJT), which allow higher efficiency power converter designs. Further progress in semiconductor technology is achieved by the discovery of an insulated-gate bipolar transistor (IGBT) that can improve the performance of IH design. IGBT has a low resistance and requires a very small power supply with a frequency of up to $100 \mathrm{kHz}$; however, a frequency of around $400 \mathrm{kHz}$ is difficult to achieve. On the contrary, static induction thyristor (SIT) has defects such as high conduction loss compared to IGBT, complicated fabrication processes, high costs, and limited application. Therefore, switching to very high frequencies can be achieved by utilizing MOSFETs.

With regard to power systems, a new soft-switched converter circuit has been developed that integrates the advantages of both conventional pulse width modulation (PWM) and resonance converters. This soft-switched converter has a switching waveform that is identical to a conventional PWM converter, except that the rise and fall edges from the waveform, as 'smoothed' without a temporary surge. In contrast to resonant converters, new soft-switched converters usually apply a controlled resonance. In this case, efficient energy conversion at high-frequency switching is absolutely necessary by manipulating the voltage or current when switching to zero. The concept is to combine the resonant tank in the converter to create an oscillation voltage (generally sinusoidal) and / or the current waveform. As a result, the zero-voltage-switching (ZVS) or zero-current-switching (ZVS) conditions can be utilized for the power switch. The ZVS principle refers to the elimination of the turn-on switching loss having the zero voltage of the switching circuit before the circuit is turned "on". On the contrary, ZVS avoids turn-off switching-loss by allowing no current to pass through the circuit right before turning it "off". The voltage or current given to the switching circuit can be made zero by using resonance as generated by the inductance-capacitance (L-C) resonance circuit; by which this topology known as "resonant-converter". Resonance is allowed to occur before and during the turn-on and turn-off process to produce ZVS and ZCS conditions, like the conventional PWM converters.

\subsection{Half-Bridge Resonance Inverter}

In terms of the number of switching devices, the inverter topology is normally used in $\mathrm{IH}$ with a single switch [58], full bridge circuit [59], half bridge series resonant [60], and half bridge inverter [61]. In this paper, a power system with a half bridge resonance series of inverter circuit has been applied. In [60], explaining the advantages of half-bridge resonance series inverters is stable switching, low-cost, and a streamlined-design. Figure 4 shows the power operating system with a half-bridge-resonant inverter, consisting of AC power supply, main electrical circuit, control unit, input-current detection-circuit, a resonance-current detection circuit, and a gate operation circuit. All procedures are required to design and test the system as shown in the block diagram. The system for $\mathrm{IH}$, however, does not need such large capacitors to produce DC flatter, as the major goal of this system is to generate heat energy. In contrast, a rough DC form helps increase the system's power factor.

AC power $(220 \mathrm{~V} / 50 \mathrm{~Hz})$ passes through the rectifier diode to be transmitted to the capacitor (C). The capacitor in the available power system is unfortunately too small in its capacity to act in leveling work, which leads to the action of an increased current at $120 \mathrm{~Hz}$, which is not the right level for DC operation. The system for $\mathrm{IH}$, however, does not need large capacitors to produce DC flatter, because the major purpose of this system is to generate heat energy. In contrast, a rough DC form helps increase the system's power factor. Based on this circuit, the leveling capacitor functions as a filter that prevents high-frequency currents from flowing into the inverter and from entering the input part. Later, the input current becomes the average current of the inverter and acts as the rippling flow to the leveling capacitor. 


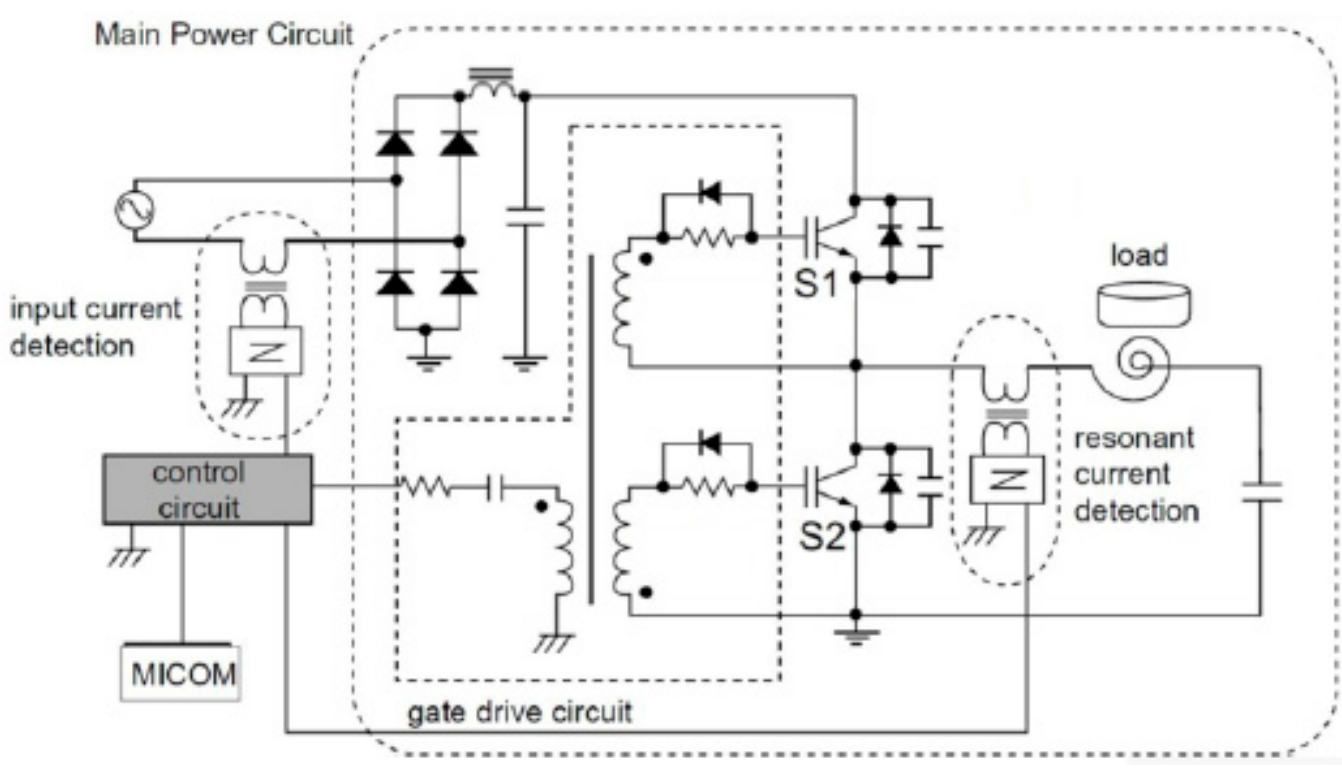

Figure 4. Half-bridge series resonant-inverter.

\section{Experimental Set-up}

\subsection{Testing of Calophyllum-Inophyllum Oil}

Calophyllum-inophyllum oil used in this study was obtained from Kebumen, East Java Province (Indonesia). This type of crude oil is an-inedible oil, which belongs to the Guttiferae family, usually called as "Nyamplung" oil in Indonesia. Nyamplung trees usually grow along coastal area and in adjacent lowlands forests, having no incubation in yielding, and seeds can be obtained throughout the year. Figure 5 shows the crude oil of Calophyllum inophyllum. The characteristics of Calophyllum inophyllum crude-oil have been tested using Gas Chromatography-Mass Spectrometry (GCMS) at the Integrated Research and Testing Laboratory, Gadjah Mada University, Yogyakarta.

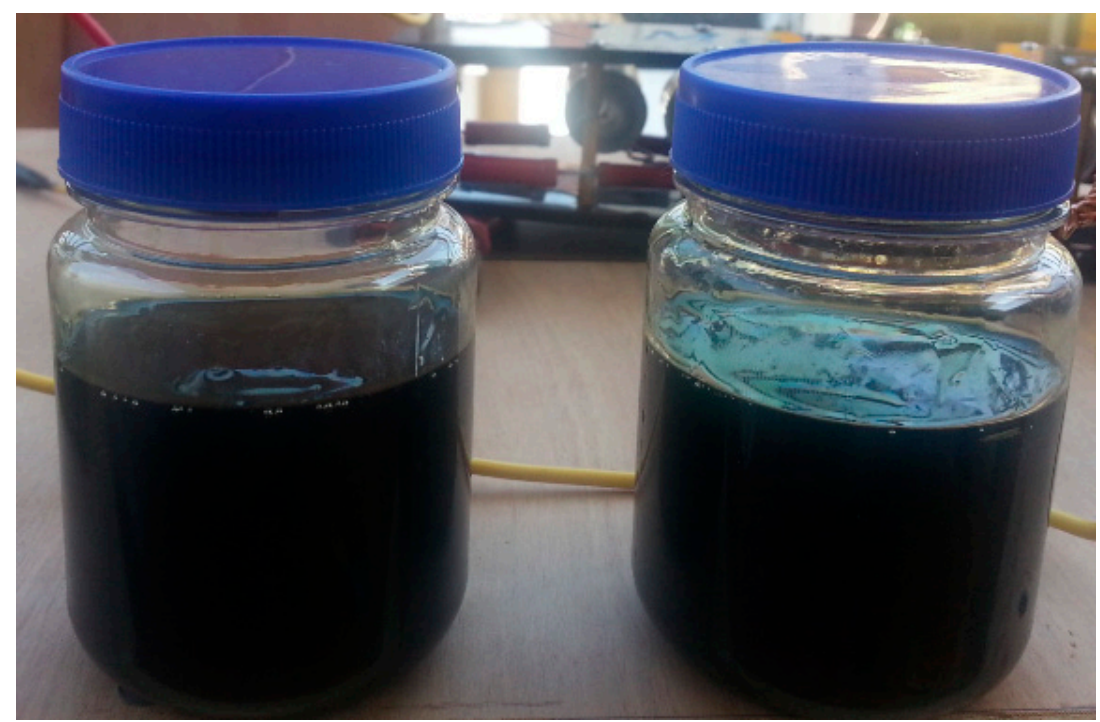

Figure 5. Calophyllum inophyllum crude oil.

Based on this test the contents of palmitic, oleic, linoleic, and stearic and acid were obtained from the oil studied. This crude oil contains the content of saturated fatty acids including stearic acid $(13.12 \%)$ and palmitic (13.92\%). In contrast, high unsaturated fatty acids, representing $72.96 \%$ mainly consists of oleic acid (69.11\%) and linoleic acid (3.85\%). 


\subsection{Biodiesel Processing}

A schematic process for producing biodiesel is illustrated in Figure 6. Firstly, biodiesel processing starts from the degumming process by utilizing the 3 heating methods at $80{ }^{\circ} \mathrm{C}$ to separate crude oil from its gum. The hotplates (conventional), microwaves, and electromagnetic induction heating are used in processing scheme as a comparison. A degumming process carried out using phosphoric acid $\left(\mathrm{H}_{3} \mathrm{PO}_{4}\right)$ as much as $5 \%(\mathrm{v} / \mathrm{v})$ of $400 \mathrm{~mL}$ Calophyllum-inophyllum oil, then it was heated to $80{ }^{\circ} \mathrm{C}$. The duration of the degumming process depends on the heating method until the color changes to light brown. Table 1 shows a comparison of the time and degumming results of the three heating methods.

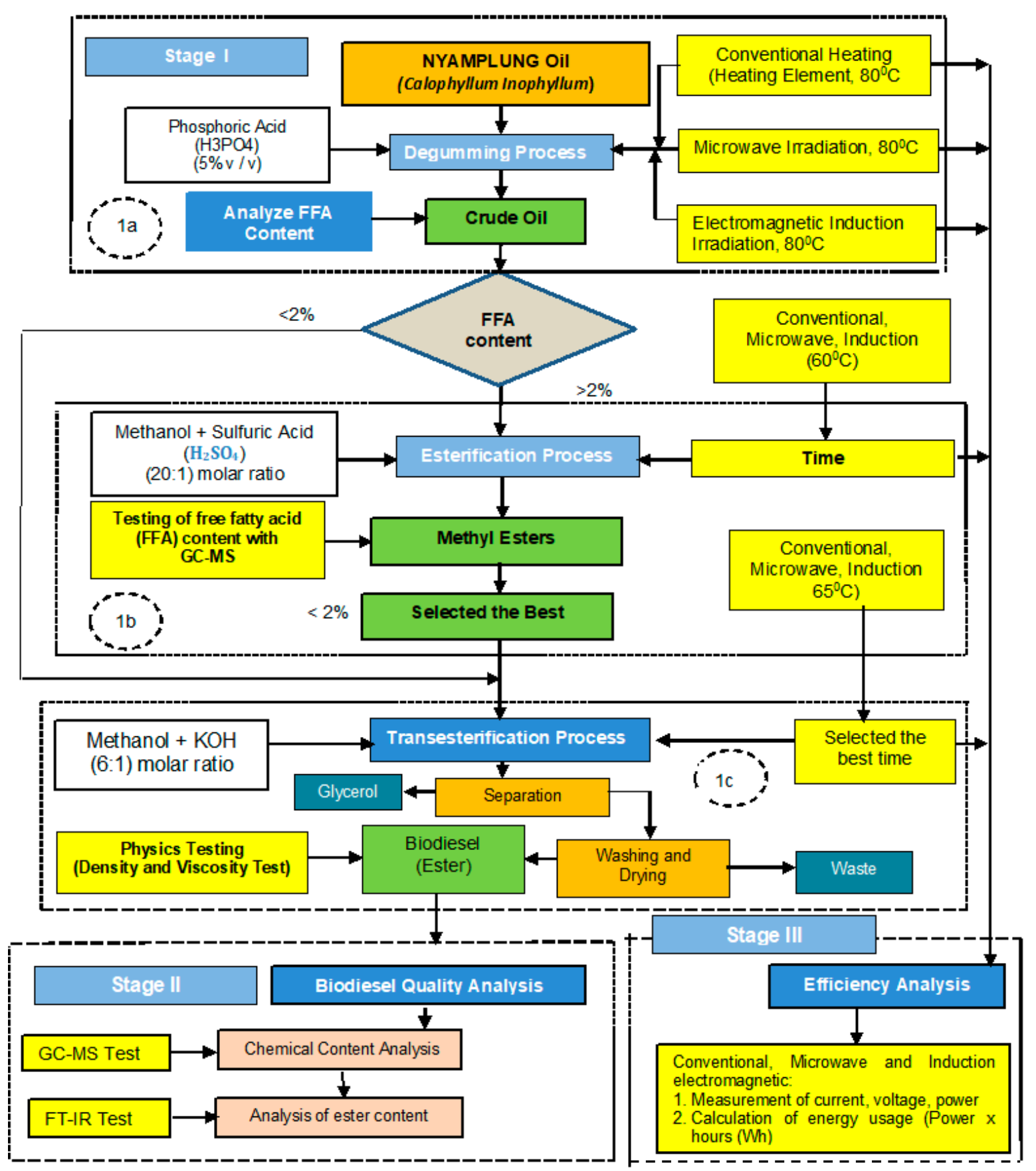

Figure 6. Schematic diagram of biodiesel process. 
Table 1. A comparison of the time and degumming results of the three heating methods.

\begin{tabular}{cccccc}
\hline \multirow{2}{*}{ Methods } & Temperature & Time & Power & FFA (\%) & FFA (\%) \\
\cline { 2 - 6 } & $\left({ }^{\circ} \mathbf{C}\right)$ & $\mathbf{( M i n )}$ & $\mathbf{( W )}$ & Before & After \\
\hline Hotplate & 80 & 15 & 600 & 20.27 & 17.66 \\
$\begin{array}{c}\text { Microwave } \\
\text { Electromagnetic }\end{array}$ & 80 & 12 & 120 & 19.82 & 17.21 \\
Induction & 80 & 3.21 & 145 & 19.7 & 17.03 \\
\hline
\end{tabular}

Secondly, Calophyllum-inophyllum oil esterification reactions were carried out in the presence of $\mathrm{H}_{2} \mathrm{SO}_{4}$ (2 wt.\%) at temperatures $60^{\circ} \mathrm{C}$ with using molar ratio of methanol-to- oil (20:1, by mole basis). According to [30], the molar ratio and dosage of catalyst become one of the most important factors in biodiesel production, whereas the humidity is one of the least important factors. Briefly, the first catalyst is dissolved in methanol and added $5 \mathrm{~g}$ of Calophyllum-inophyllum oil is put in a $100 \mathrm{~mL}$ beaker. The mixture of methanol and catalyst $\mathrm{H}_{2} \mathrm{SO}_{4}$ was put into Erlenmeyer and stirred with a magnetic stirrer for $5 \mathrm{~min}$. The beaker glass is filled with a mixture of methanol, Calophyllum-inophyllum oil, $\mathrm{H}_{2} \mathrm{SO}_{4}$, and it is heated using 3 heating methods by keeping the temperature up to $60{ }^{\circ} \mathrm{C}$. After esterification, testing is carried out to determine the content of FFA. If the FFA is still high or in above $2 \%$, the esterification process is repeated for 2 times until the FFA becomes precisely low (below $2 \%$ ). After that, methanol must be removed and separated from oil product using a $100 \mathrm{~mL}$ separatory funnel for the purification stage. The product is washed with hot distilled water $\left(>80^{\circ} \mathrm{C}\right)$ to remove the remaining acid in the product, continuing until the washing water shows $\mathrm{pH} \sim 7$.

Further, the transesterification process is performed as a chemical reaction involving triglycerides and alcohol in the presence of a catalyst to form esters and glycerol. The transesterification process of Nyamplung oil is obtained at a methanol-to-oil molar ratio, $6: 1$ and $\mathrm{KOH}$ of $2 \%$ catalyst with a temperature of $65^{\circ} \mathrm{C}$. The time period of the transesterification process depends on the heating method used as seen in the oil color changes and the formed glycerol. Finally, the glycerol which is formed must be separated from biodiesel to be washed and dried.

\subsection{Induction Heating Irradiation}

In this study, an electromagnetic induction heater has been utilized in processing Calophyllum inophyllum biodiesel. The equipment specifications have been detailed in Table 2. The schematic diagram of the experimental set up is ills ustrated in Figure 7. The electromagnetic induction heat radiation induced by the metal mounted inside the coil is absorbed by the sample oil, which may lead to the appearance of warming in the sample. Heating with induced magnetic field radiation is faster and is evenly distributed along the metal mounted inside the coil, as it does not transfer heat from the outside. The duration of induction given to metals affects the rise in temperature/heat of the metal which affects the passage of the transesterification reaction. The greater the temperature given, the transesterification reaction runs faster and results in biodiesel conversion.

Table 2. Equipment specification.

\begin{tabular}{ccc}
\hline No. & Name & Specification \\
\hline 1. & Dc Voltage & 30 Volts \\
2. & Power Input & 200 watts \\
3. & Current Output & 1.2 Amps \\
4. & Temperature & $0-1000^{\circ} \mathrm{C}$ (adjustable) \\
\hline
\end{tabular}

Vibrations in molecules induced by induction heat radiation will produce an equal heat on the molecule, where the resulting induction heat penetrates and excites the molecules evenly, not solely in the surface. Induced heating radiation can speed up the reaction by vibrating the reactant molecule quickly. The longer the radiation time is given to the transesterification reaction, the heat generated by the reactant molecule's vibration will be greater until reaching its optimum state. The transesterification 
time at $65{ }^{\circ} \mathrm{C}$ has been controlled automatically by a microcontroller. Output data such as temperature, current, power, and voltage are displayed and stored on a laptop.

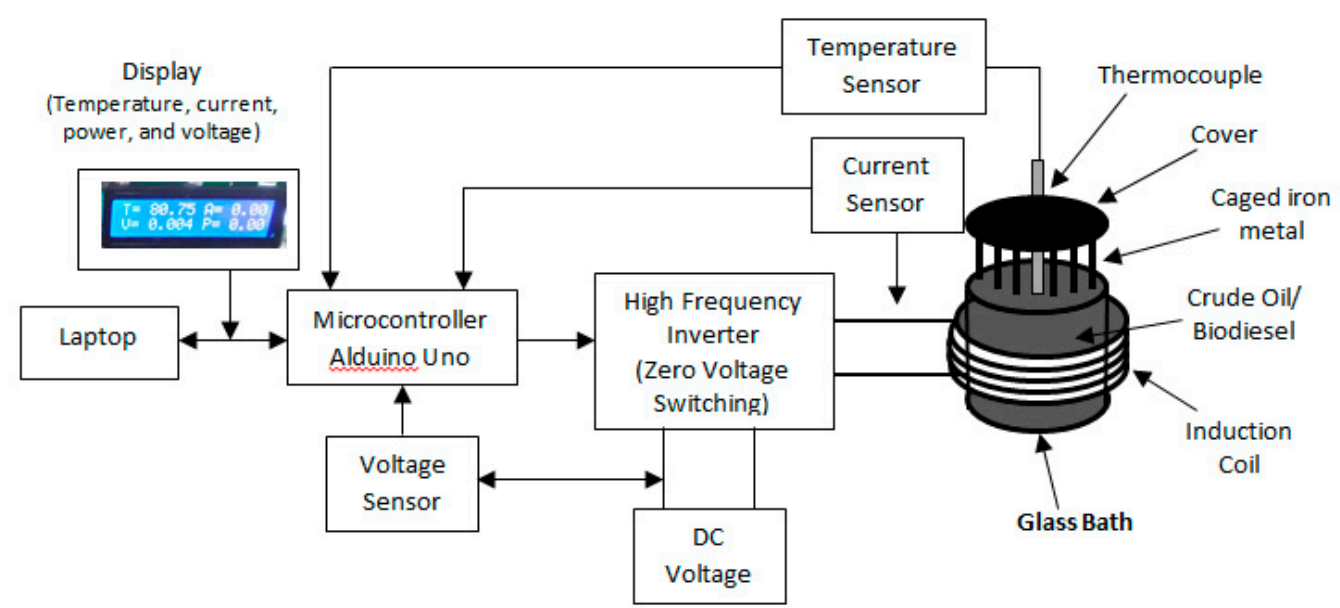

Figure 7. Schematic diagram of electromagnetic induction irradiation.

Eddy currents have the most dominant role in the induction of the heating process. The heat generated on the material depends on the number of eddy currents as induced by the inductor winding. When the winding is fed by alternating current, a magnetic field will occur around the conductor wire. The magnetic field varies according to the current flowing in the coil. According to [62], if there is conductive material around the changing magnetic field, the conductive material will flow a current called eddy current. The Eddy current principle is based on Faraday's law which states that when a conductor is cut out the force lines of the magnetic field or electromotive force (EMF), it will be inducted into the conductor. The amount of EMF depends on (1) the size, strength, and magnetic field density; (2) on the speed at which the magnetic force lines are cut; (3) and on the quality of conductors.

\section{Result}

\subsection{Characteristics of IH Irradiation}

One method of heating to allow the reaction to run faster is performed to achieve a transesterification reaction by using the electromagnetic induction of heat radiation. The electromagnetic IH radiation as induced by the metal mounted inside the coil is absorbed by the sample, which may lead to the appearance of warming in the sample. Heating with induced magnetic field radiation is faster and evenly distributed along the metal mounted inside the coil, rather than by transferring heat from the outside materials. The duration of induction given to metals affects the rise in temperature/heat of the metal which affects the passage of the transesterification reaction. The greater the temperature given, the transesterification reaction runs faster resulting in more biodiesel conversion.

Vibrations in molecules induced by IH radiation will produce an equal heat on the molecule, where the resulting induction heat penetrates and excites the molecules evenly, not solely in the surface. Induced heating radiation can speed up the reaction by vibrating the reactant molecule quickly. The longer the radiation time is given to the transesterification reaction; the heat generated by the reactant molecule's vibration will be greater, resulting the transesterification reaction will reach its optimum state at any time the trial. Eddy currents have the most dominant role in the induction heating process. The heat generated in the material depends on the amount of eddy current as induced by the inductor winding. When the windings are energized by alternating current, a magnetic field will occur around the conductor wire. Magnetic fields vary according to the current flowing in the coil.

Technically, induction heaters have characteristics that are able to release heat in a relatively short time due to high energy density. By the induction, it is possible to reach high temperatures. Heating 
can be performed at a specific location where the system can be made to work automatically. Induction heating, in general, has high energy efficiency, depending on the characteristics of the heated material as any heating losses can be minimized. According to [63], several factors determine the number of eddy currents in the metal, including: (1) the magnetic field inducing the metal; (2) and the metal materials used to generate heat (the smaller the resistance of the metal type, the metal is better as the object of heat); (3) the metal surface area (the more surface area of the metal, the more eddy currents will be on the metal surface); and (4) the greater the frequency, the more the magnetic field is generated. In addition, there are several advantages of using induction heater, including heat is generated directly inside the barrel wall; heat can be applied uniformly across the barrel; cold element operation is performed, having unlimited time; faster startup time; and more energy-efficient.

\subsection{Advantages of Electromagnetic Induction Methods}

The biodiesel production process must be refined to maximize material value and minimize costs. According to [64], if we can make low cost and high-acid-value oil available as resources, the cost of biodiesel production will be reduced significantly. However, these low-cost oils cannot be used to produce biodiesel directly because they usually contain a large amount of FFAs. They have to undergo a preparatory procedure to lower the acid value to a specific value. In addition, in industrialization processes, it not only saves time and effort but is also low-cost $[65,66]$. Therefore, low energy potential and lack of efficient technologies are the problems with these feedstocks for the commercial production of biodiesel [67].

Figure 8 shows a comparison of the testing result in biodiesel manufacturing processes among the conventional, microwave and electromagnetic induction. It is concluded that electromagnetic induction technology provides a great opportunity in the future production process. Compared to other methods, the proposed new method has a precisely short time at every stage of the production process such as in degumming (3.2 $\mathrm{min})$, esterification $(18.13 \mathrm{~min})$, and transesterification $(0.43 \mathrm{~min})$. Overall, the time required for processing biodiesel is hotplate (130 $\mathrm{min})$, microwave (112 $\mathrm{min})$, and electromagnetic induction $(21.93 \mathrm{~min})$. Here, it appears that there is a significant time difference from the use of the induction method compared to the other two heating methods. With the achievement of faster time at each stage of biodiesel processing has advantages, such as reducing production costs, saving energy, and improving the quality of biodiesel. Another advantage is the cost of fabricating electromagnetic induction is cheaper compared to microwave and hotplate (in this study the cost of fabricating electromagnetic does not exceed $\$ 100 \mathrm{US}$ ).

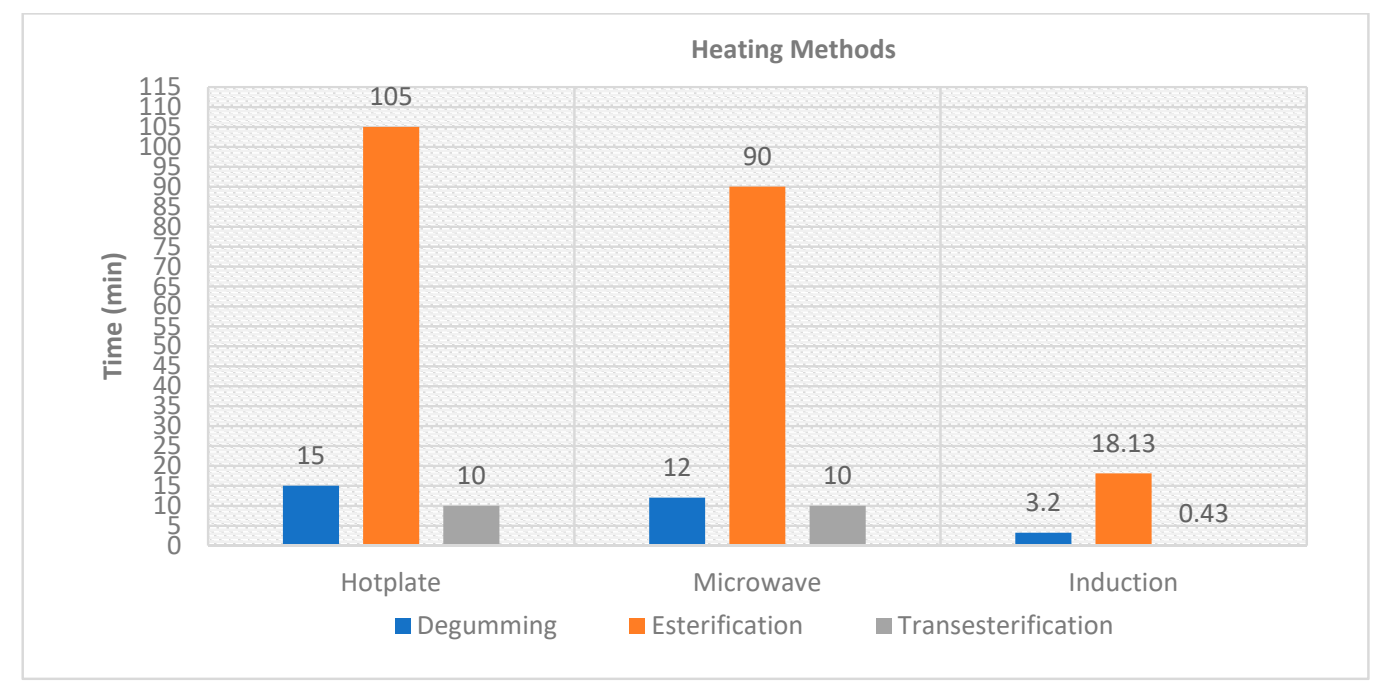

Figure 8. Time comparison of biodiesel production among conventional, microwave, and induction electromagnetic. 


\subsection{Analysis Free Fatty Acid (FFA)}

\subsubsection{Esterification Process}

Esterification is the process of reacting FFA into esters with short-chain alcohols (methanol or ethanol) to produce fatty acid methyl ester (FAME) and water. The esterification process with an acid catalyst is required if vegetable oil contains FFA at above $2 \%$. If oil with a high FFA level $(>2 \%)$ is directly transesterified with a $\mathrm{KOH}$ catalyst, the FFA will react with the catalyst to form soap. The formation of large amounts of soap can inhibit the separation of glycerol from methyl esters and results in the formation of emulsions during the washing process. Esterification is employed as a preliminary process to convert FFA to methyl ester to reduce the levels of FFA in vegetable oils and is later transesterified with a base catalyst (to convert triglycerides to methyl esters).

Esterification is the conversion stage from FFA to esters. Esther reacts the fatty oils with alcohol. To encourage the reaction to proceed, the methanol reactant must be added in such excessive amounts (usually greater than 10 times of the stoichiometric ratio) and the water product following the reaction must be removed from the reaction phase, which is the oil phase. The 20:1 (methanol to oil) molar ratio between oil and methanol is utilized in this study. Heat treatment is carried out at an average temperature of $60^{\circ} \mathrm{C}$ with a period of time depending on the characteristics of the applied heating method. To maximize the biodiesel yield from oils with high FFA levels, esterification must be performed to reduce the level of FFAs prior to transesterification $[68,69]$. Therefore, the esterification process is carried out twice [70], as the first esterification process obtains FFA content which is still high at above $2 \%$. Table 3 presents the comparison of FFA values from the esterification results for the 3 (three) heating methods used.

Table 3. Comparison of Free Fatty Acid (FFA) values from esterification results among the three heating methods with a molar ratio of $20: 1$, and $2 \% w / w$ (of oil) $\mathrm{H}_{2} \mathrm{SO}_{4}$.

\begin{tabular}{cccccc}
\hline \multirow{2}{*}{ Method } & \multirow{2}{*}{ Temperature $\left({ }^{\circ} \mathbf{C}\right)$} & \multicolumn{2}{c}{ Esterfication I } & \multicolumn{2}{c}{ Esterification II } \\
\cline { 3 - 6 } & & Time (Min) & FFA (I) (\%) & Time (Min) & FFA (II) (\%) \\
\hline Hotplate & 60 & 75 & 6.8 & 30 & 1.7 \\
Microwave & 60 & 75 & 3.59 & 15 & 1.43 \\
Induction & 60 & 12 & 5.8 & 6.13 & 1.6 \\
Electromagnetic & & & & & \\
\hline
\end{tabular}

\subsubsection{Transesterification Process}

This stage becomes the main stage in this study, where triglycerides are the main components of oil converted into biodiesel and glycerol. The product of pretreatment was heated to $65^{\circ} \mathrm{C}$ in the three methods for transesterification with 6:1 M ratio of methanol and $2 \% w / w$ (of oil) $\mathrm{KOH}$ in the same setup. According to [71] the optimal temperature in the transesterification process with a $\mathrm{KOH}$ catalyst is $65^{\circ} \mathrm{C}$. Comparative data from the results of the transesterification of the three heating methods are illustrated in Table 4. Figures 9 and 10 show the transesterification process by using electromagnetic induction, respectively. The biodiesel production using electromagnetic induction has a higher FAME value than in conventional and microwave.

Table 4. A comparison of the transesterification process of Nyamplung oil with a molar ratio of 6:1, and $2 \%(w / w) \mathrm{KOH}$.

\begin{tabular}{ccccc}
\hline Method & Temperature $\left({ }^{\circ} \mathbf{C}\right)$ & Time (Min) & FFA (\%) & FAME (\%) \\
\hline Hotplate & 65 & 10 & 0.56 & 35,1 \\
Microwave & 65 & 10 & 0.42 & 53.66 \\
Induction & 65 & 0.43 & 0.4 & 65.96 \\
Electromagnetic & & & & \\
\hline
\end{tabular}




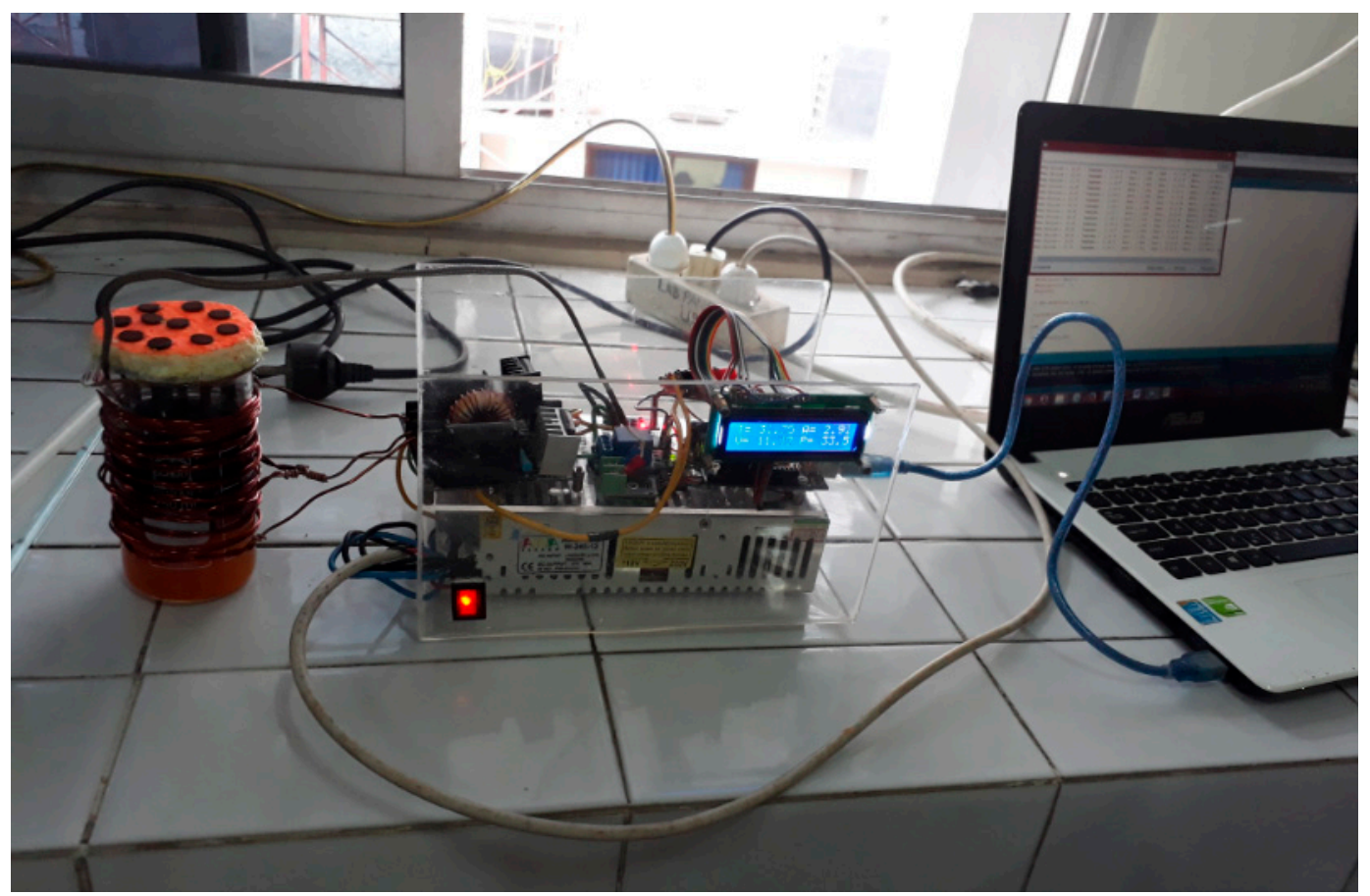

Figure 9. The esterification process using electromagnetic induction.

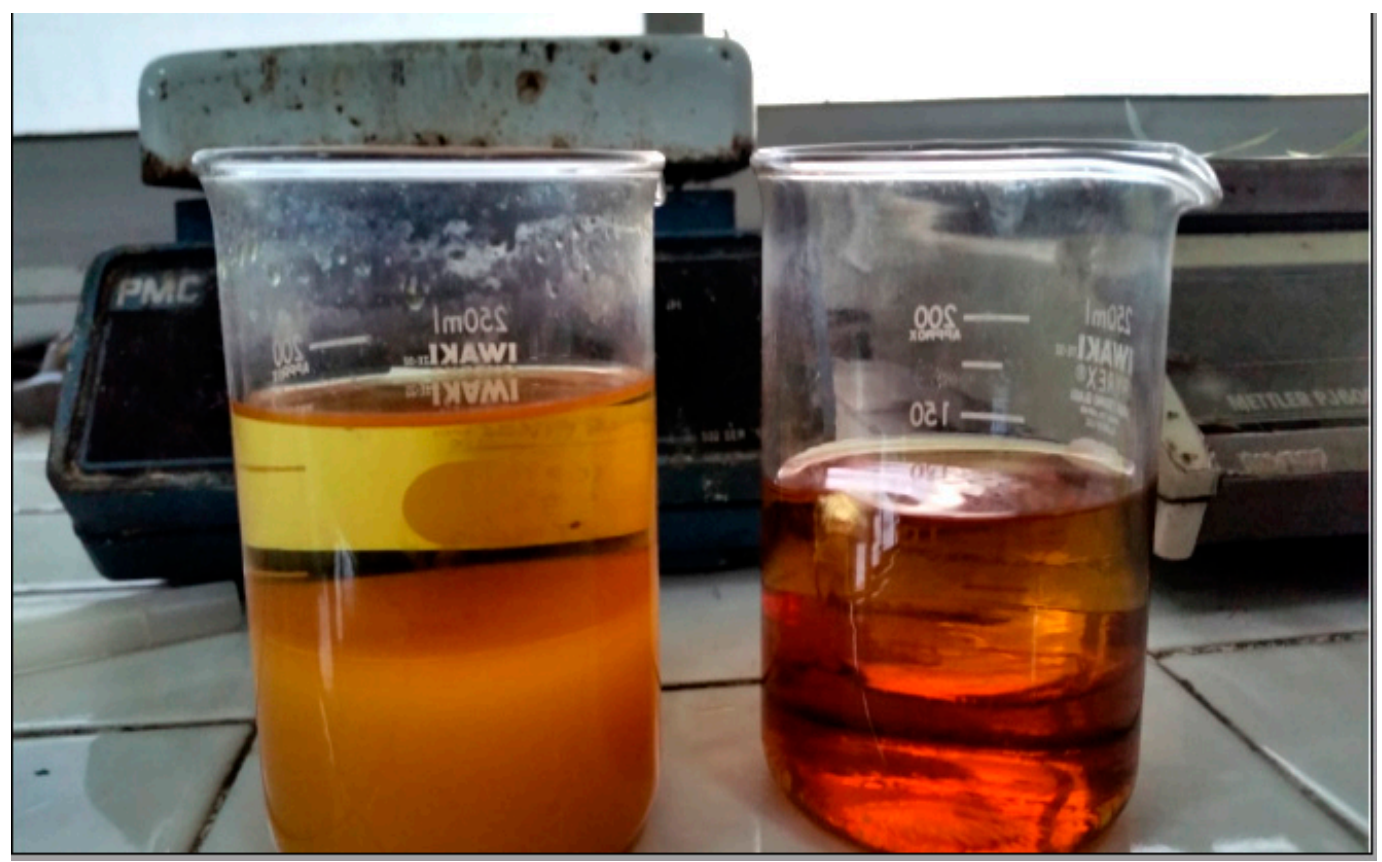

(a)

(b)

Figure 10. Fatty acid metil ester (FAME): (a) esterification (b) biodiesel.

\subsection{Analysis of Energy Use}

Based on the measurement results, the amount of power utilized by all heating methods is the multiplication of voltage and output current. Energy consumption is calculated between the time (hour, h) multiplier and the power (Watt, W). Based on Table 5, it is apparent that energy with electromagnetic induction method is more efficient compared to that in conventional and microwave method, that is, $47.29 \mathrm{Wh}$. The amount of energy obtained is based on the multiplication of the 
overall time in the degumming, esterification and transesterification steps by the amount of heating equipment power.

Table 5. Comparison of energy consumption for Calophyllum inophyllum oil (200 mL).

\begin{tabular}{ccccc}
\hline \multirow{2}{*}{ Methods } & \multicolumn{3}{c}{ Energy Consumption $\mathbf{( W h )}$} & \multirow{2}{*}{ Total Energy (Wh) } \\
\cline { 2 - 4 } & Degumming & Esterification & Transesterification & \\
\hline Hotplate & 150 & 900 & 96 & 1.146 \\
Microwave & 19.2 & 50 & 6.4 & 75.6 \\
Electromagnetic & 7.68 & 38.7 & 0.91 & 47.29 \\
Induction & & & & \\
\hline
\end{tabular}

\subsection{Testing of Viscosity and Density}

The viscosity of biodiesel plays an important role in the fuel injection process. A precisely small viscosity causes leaks in the fuel injection pump. Conversely, too high viscosity will produce large droplets of fuel and will have high momentum and collide with the cylinder wall, but the injection pump cannot fog properly. Density is related to the value of heat and to the energy produced by a diesel engine. Low density will produce high calorific value and vice versa. Density is a parameter marking the success of the transesterification reaction. Fulfillment of density parameters indicates that the biodiesel purification process is successful. The lack of biodiesel due to impurity can produce high-density values. Table 6 illustrates the Nyamplung biodiesel properties compared with those of SNI, ASTM D6751, ASTM PS 121, C1 Biodiesel, and EN 14214. The test results present that the obtained biodiesel viscosity is $5.54 \mathrm{Cst}$, meeting the requirements of the Indonesian National Standard (SNI) in the fuel injection process between 2.3 and 6.0 Cst.

Table 6. Nyamplung biodiesel properties compared with those of SNI, ASTM D6751, ASTM PS 121, C1 Biodiesel, and EN 14214.

\begin{tabular}{|c|c|c|c|c|c|c|}
\hline \multirow{2}{*}{ Properties } & \multirow{2}{*}{$\begin{array}{l}\text { ASTM D6751 } \\
\text { (USA) }\end{array}$} & \multirow{2}{*}{$\begin{array}{c}\text { ASTM PS } \\
121\end{array}$} & \multirow{2}{*}{ EN 14214} & \multirow{2}{*}{$\begin{array}{c}\text { C1 } \\
\text { Biodiesel }\end{array}$} & \multirow{2}{*}{ SNI } & $\begin{array}{c}\text { Nyamplung } \\
\text { Biodiesel }\end{array}$ \\
\hline & & & & & & (This Study) \\
\hline Acid value (mg KOH/g) & $<0.5$ & $<0.5$ & $<0.5$ & 0.34 & 0.8 & 0.8 \\
\hline Density $(20 \mathrm{C})(\mathrm{g} / \mathrm{mL})$ & $0.87-0.9$ & 0.7328 & No specific & 0.877 & $0.850-0.890$ & 0.882 \\
\hline $\begin{array}{l}\text { Kinematic viscosity, } \\
40^{\circ} \mathrm{C}\left(\mathrm{mm}^{2} / \mathrm{s}\right)\end{array}$ & $1.9-6.0$ & $1.9-6.0$ & $3.5-5.0$ & 5.6872 & $2.3-6.0$ & 5.54 \\
\hline
\end{tabular}

\subsection{GC-MS Analysis}

The biodiesel composition was quantified using Gas Chromatography - Mass Spectrometer detector (GCMS) testing at the Integrated MIPA Laboratory, State University of Malang. Based on the results of GC-MS testing that has been done, it can be identified the compound components of the Nyamplung oil biodiesel as shown in Table 7.

Table 7. Major Components Based on GC-MS Analysis.

\begin{tabular}{cccccc}
\hline Component & Peak & Detection Time & Identified Compounds & Molecular Formula & Percentage (\%) \\
\hline I. & 6 & 35.006 & Linoleic acid methyl ester & $\mathrm{C}_{19} \mathrm{H}_{34} \mathrm{O}_{2} \mathrm{C}_{19} \mathrm{H}_{34} \mathrm{O}_{2}$ & $16.78+$ \\
II. & 7 & 35.109 & Oleic acid methyl ester & $\mathrm{C}_{19} \mathrm{H}_{36} \mathrm{O}_{2}$ & $17.17=33.95$ \\
III. & 8 & 35.388 & Stearic acid methyl ester & $\mathrm{C}_{19} \mathrm{H}_{38} \mathrm{O}_{2}$ & 20.06 \\
IV. & 9 & 35.997 & Palmitic acid methyl ester & $\mathrm{C}_{17} \mathrm{H}_{34} \mathrm{O}_{2}$ & 18.62 \\
\hline
\end{tabular}

As shown in Table 7, four fatty acids were clearly detected in the oil extracted by GC from the Nyamplung oil. The most major component was linoleic methyl ester $33.95 \%$ having a molecular mass of $294 \mathrm{~m} / \mathrm{z}$, at peaks 6 and 7 as shown in Figure 11. The percentage of the second major component of oleic methyl ester is $20.06 \%$ which has a molecular mass of $296 \mathrm{~m} / \mathrm{z}$ at peak 8 (Figure 12). Figures 13 
and 14 show stearic methyl ester with a mass of $298 \mathrm{~m} / \mathrm{z}$ and palmitic methyl esters with a mass of $2970 \mathrm{~m} / \mathrm{z}$ are the third and fourth most components at $18.62 \%$ and $17.12 \%$ respectively.

Hit=:1 Entry:232840 Library:WILEY8 LIB

SI:94 Formula:C19H34O2 CAS:112-63-0 MolWeight:294 RetIndex:0

CompName:9,12-OCTADECADIENOIC ACD (Z,Z)-, METHYL ESTER \$\$ METHYL (9Z,12Z)-9,12-OCTADECADIENOATE \# \$\$ 9,12-OCTA

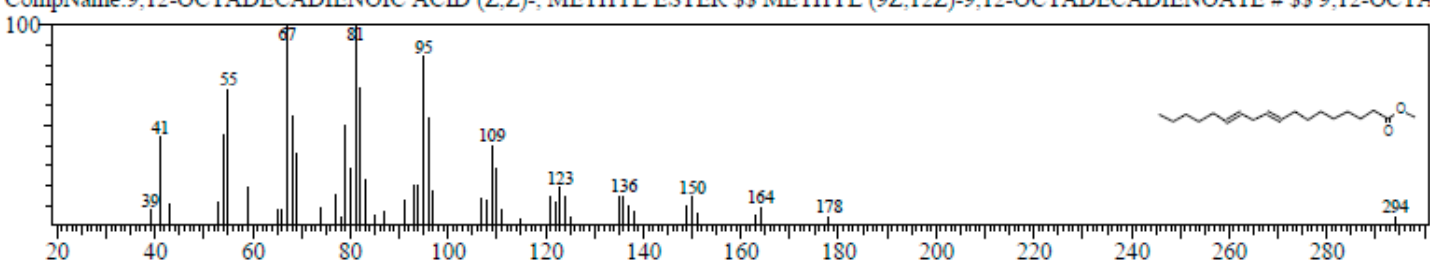

(a)

Hit=:1 Enty:232840 Libray:TVILEYS.IIB

SI-85 Fonmula:C19H34O2 CAS:112-63-0 MolTVeight:294 RetIndex:0

CompName-9,12-OCTADECADIENOIC ACID (Z,Z)-, METHYL ESTER \$\$ METHYZ (9Z,12Z)-9,12-OCTADECADIENOATE =\$S 9,12-OCTA

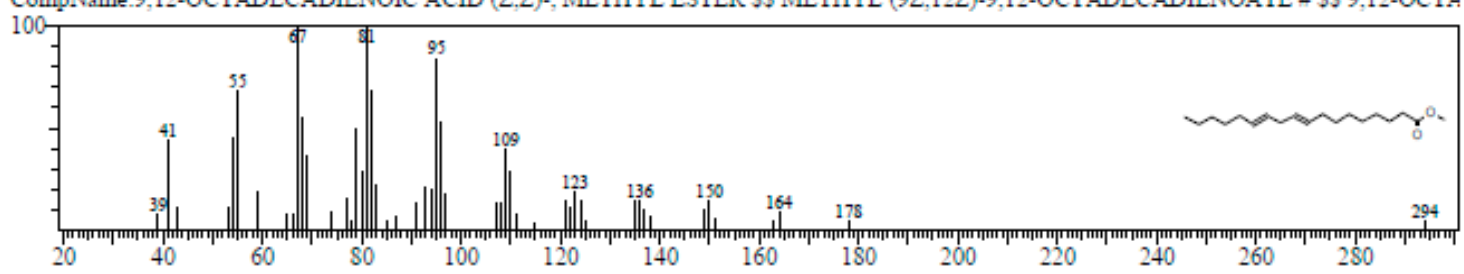

(b)

Figure 11. Fragmentation of linoleic acid methyl ester: (a) peak 6; (b) peak 7.

Hit\#: 1 Entry:235420 Library:WILEY8.LIB

SI:88 Formula:C19H36O2 CAS:112-62-9 MolWeight:296 RetIndex:0

CompName:9-OCTADECENOIC ACID (Z)-, METHYL ESTER \$\$ 9-OCTADECENOIC ACID, METHYL ESTER \$\$ METHYL (9Z)-9-OCTAD]

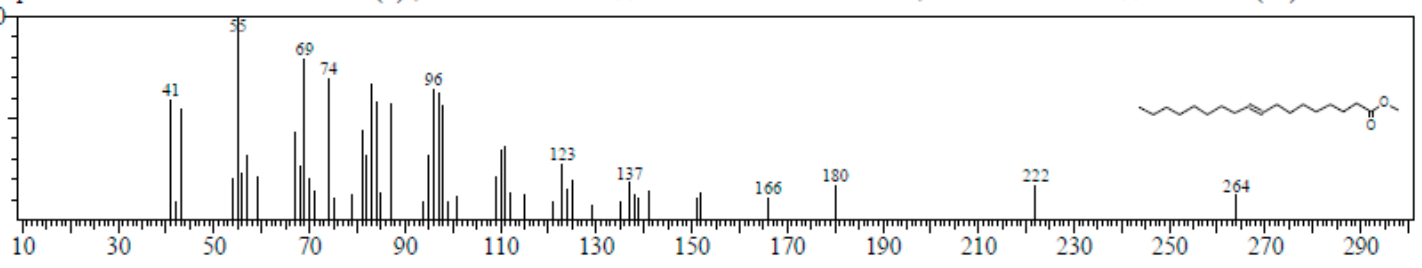

Figure 12. Fragmentation of oleic acid methyl ester.

Hit\#: 1 Entry:237863 Library:WILEY8.LIB

SI:95 Formula:C19H3802 CAS:112-61-8 MolWeight:298 RetIndex:0

CompName:OCTADECANOIC ACID, METHYL ESTER \$\$ METHYL OCTADECANOATE \$\$ STEARIC ACID METHYL ESTER \$\$ AI3-079,

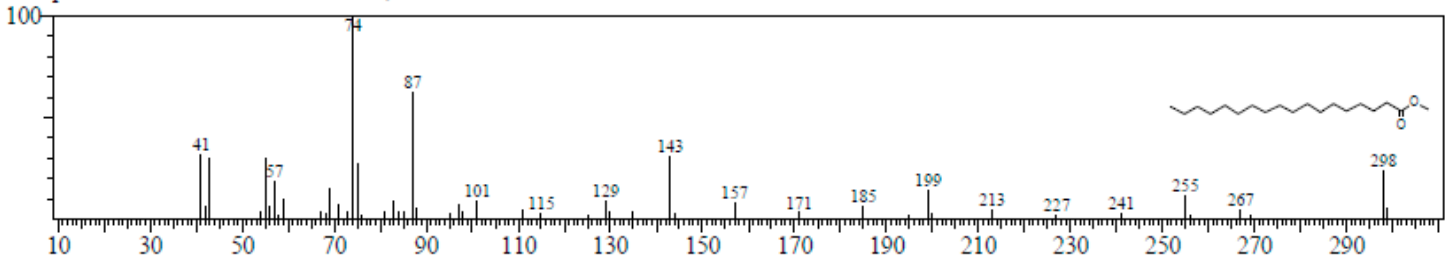

Figure 13. Fragmentation of stearic acid methyl ester.

Hit\#:1 Entry:201918 Library:WILEY8.LIB

SI:95 Formula:C17H34O2 CAS:112-39-0 MolWeight:270 RetIndex:0

CompName:HEXADECANOIC ACID, METHYL ESTER \$\$ METHYL HEXADECANOATE \$\$ PALMITIC ACID METHYL ESTER \$\$ AI3-03

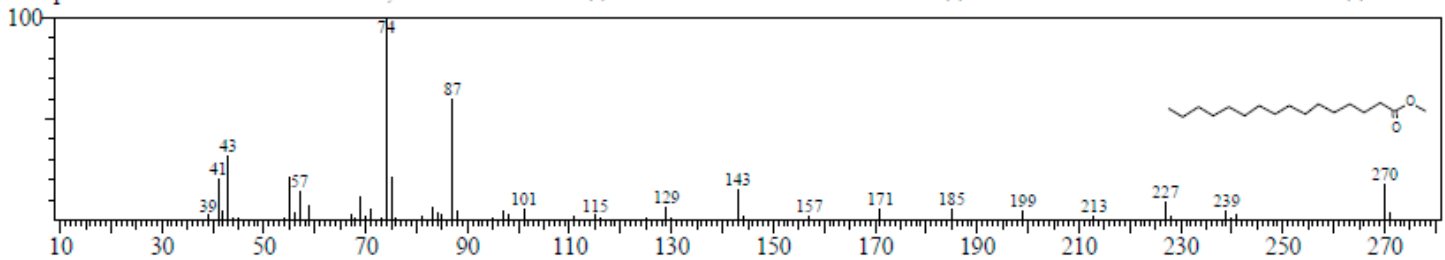

Figure 14. Fragmentation of palmitic acid methyl ester. 


\section{Discussion}

Some ways to reduce the cost of biodiesel production are to find optimal parameters, including reaction temperature, reaction time, amount of catalyst to be added to the reaction, and the methanol-to-oil ratio. Previous researchers have experimented with base catalytic reactions, acid catalytic reactions, and enzymatic transesterification and have found that a base-catalytic reaction obtained the best result. Biodiesel can be produced under a lower temperature with a base catalyst, whereas a transesterification reaction with an acid catalyst requires higher temperatures and longer reaction time [72,73]. On the other hand, the use of longer reaction times in biodiesel processing has an impact on production costs. Generally, the biodiesel production process is performed by a heating device such as a hotplate or heating coil. With the development of high technology, the microwave radiation method in biodiesel making becomes a smart choice compared to conventional systems. An alternative heating system of "microwave irradiation" has been applied in transesterification reactions in recent years. Microwaves are considered as electromagnetic radiation that represents non-ionizing radiation influencing molecular motions such as ion migration or dipole rotation but that does not change the molecular structure [74,75].

According to [50], the advantage of using a microwave in the biodiesel process is that it efficiently accelerates the transesterification process through short reaction time. In addition, a drastic reduction in the number of products is obtained, a short separation time is obtained and a high yield of a very pure product is achieved in a short-time [76]. Compared to conventional systems, production costs are also reduced and fewer products occur. Therefore, microwave heating is more preferred compared to conventional methods, where heating time is very slow and is inefficient because the transfer of energy to the sample depends on the convection current and the thermal conductivity of the reaction mixture. However, a shorter heating reaction has been achieved through electromagnetic induction than in microwave technology.

Experimentally, a comparison of 3 methods in the production process of Calophyllum inophyllum biodiesel is attached. In the transesterification process, electromagnetic induction requires only $0.43 \mathrm{~min}$, compared to both in microwave and conventional methods, lasting for $10 \mathrm{~min}$. Likewise, other stages such as degumming and esterification, such as in Figure 8 present a significant time difference among the three methods. Some characteristics of the electromagnetic induction method show better progress than the others, such as the shorter time, more energy saving, more qualified FAME, better viscosity, and higher yield. Therefore, the findings of this method present promising expectations for biodiesel production.

\section{Conclusions}

An experimental investigation has been carried out to process Calophyllum inophyllum oil into biodiesel by a new method of electromagnetic induction. The most important conclusions obtained are summarized as follows:

1. Biodiesel produced from Calophyllum inophyllum oil with electromagnetic induction radiation generally meets ASTM D6751, C1 biodiesel, EN 14214, and SNI standards, so it can be used as an alternative for biodiesel processing.

2. Under optimal conditions, the energy consumption of electromagnetic induction is more efficient than the hotplate and microwave method. Compared to heating both hotplate and microwave, the reaction time is significantly reduced.

3. Due to having faster reaction time in the transesterification process, the FAME value obtained is higher than the hotplate and microwave. The optimal condition for this experiment is the molar ratio of methanol to oil $6: 1,2 \%(\mathrm{~b} / \mathrm{b})$ of $\mathrm{KOH}$ catalyst, a reaction temperature of $65^{\circ} \mathrm{C}$, the reaction time of $0.43 \mathrm{~min}$, and FAME of $65.96 \%$.

4. Compared to microwaves and hotplate, electromagnetic induction is achieved at a shorter time in all stages of degumming, esterification, and transesterification. Overall, the time needed to 
process biodiesel is hotplate (130 $\mathrm{min})$, microwave (112 $\mathrm{min})$, and electromagnetic induction (21.93 $\mathrm{min})$. As a result, the overall energy used from the biodiesel production stage is also more economical and efficient.

Author Contributions: Conceptualization, S.K., (S.S.) Soedjito Soeparman; Methodology, S.K., L.H.; Validation, S.K., S.S.Y. and (S.S.) Sudirman Syam; Formal Analysis, S.K., L.H.; Data Curation, (S.S.) Soedjito Soeparman; Writing-Original Draft Preparation, S.K.; Writing-Review \& Editing, (S.S.) Sudirman Syam; Supervision, (S.S.) Sodjito Soeparman; Project Administration, S.K.; Funding Acquisition, S.K.

Funding: This research was funded by the Ministry of Research, Technology and Higher Education in the Doctoral Grant Research with contract number 42/UN15.19/LT/2018.

Acknowledgments: The authors would like to acknowledge the support of the Laboratory of Electrical Engineering, University of Nusa Cendana-Kupang and scholarship support from the Ministry of Research Technology and Higher Education.

Conflicts of Interest: The authors declare no conflict of interest.

\section{References}

1. Melero, J.A.; Bautista, L.F.; Morales, G.; Iglesias, J.; Sánchez-Vázquez, R. Biodiesel production from crude palm oil using sulfonic acid-modified mesostructured catalysts. Chem. Eng. J. 2009, in press. [CrossRef]

2. Alkabbashi, A.N.; Alam, M.Z.; Mirghani, M.E.S.; Al-Fusaiel, A.M.A. Biodiesel production from crude palm oil by transesterification process. J. Appl. Sci. 2009, 9, 3166-3170. [CrossRef]

3. Crabbe, E.; Nolasco-Hipolito, C.; Kobayashi, G.; Sonomoto, K.; Ishizaki, A. Biodiesel production from crude palm oil and evaluation of butanol extraction and fuel properties. Process Biochem. 2001, 37, 65-71. [CrossRef]

4. Harsono, S.S. Biodiesel production from palm oil technology. Res. J. Agric. Sci. 2011, 43, 80-85.

5. Kaieda, M.; Samukawa, T.; Matsumoto, T.; Ban, K.; Kondo, A.; Shimada, Y.; Noda, H.; Nomoto, F.; Ohtsuka, K.; Izumoto, E.; et al. Biodiesel fuel production from plant oil catalyzed by Rhizopus oryzae lipase in a water-containing system biofuel's engineering process technology without an organic solvent. J. Biosci. Bioeng. 1999, 88, 627-631. [CrossRef]

6. Samukawa, T.; Kaieda, M.; Matsumoto, T.; Ban, K.; Kondo, A.; Shimada, Y.; Noda, H.; Fukuda, H. Pretreatment of immobilized candida antarctica lipase for biodiesel fuel production from plant oil. J. Biosci. Bioeng. 2000, 90, 180-183. [CrossRef]

7. Silva, C.C.C.M.; Ribeiro, N.F.P.; Souza, M.M.V.M.; Aranda, D.A.G. Biodiesel production from soybean oil and methanol using hydrotalcites as catalyst. Fuel Process. Technol. 2010, 91, 205-210. [CrossRef]

8. Cao, W.; Han, H.; Zhang, J. Preparation of biodiesel from soybean oil using supercritical methanol and co-solvent. Fuel 2005, 84, 347-351. [CrossRef]

9. Lee, J.H.; Kwon, C.H.; Kang, J.W.; Park, C.; Tae, B.; Kim, S.W. Biodiesel production from various oils under supercritical fluid conditions by candida antarctica lipase B using a stepwise reaction method. Appl. Biochem. Biotechnol. 2009, 156, 454-464. [CrossRef]

10. Yu, D.; Tian, L.; Wu, H.; Wang, S.; Wang, Y.; Ma, D.; Fang, X. Ultrasonic irradiation with vibration for biodiesel production from soybean oil by Novozym. Process Biochem. 2010, 45, 519-525. [CrossRef]

11. Chen, C.-H.; Chen, W.-H.; Chang, C.-M.J.; Lai, S.-M.; Tu, C.-H. Biodiesel production from supercritical carbon dioxide extracted Jatropha oil using subcritical hydrolysis and supercritical methylation. J. Supercrit. Fluids 2010, 52, 228-234. [CrossRef]

12. Chena, C.-R.; Cheng, Y.-J.; Ching, Y.-C.; Hsiang, D.; Chang, C.-M. Green production of energetic Jatropha oil from de-shelled Jatropha curcas L. seeds using supercritical carbon dioxide extraction. J. Supercrit. Fluids. 2012, 66, 137-143. [CrossRef]

13. Koh, M.Y.; Ghazi, T.I.M. A review of biodiesel production from Jatropha curcas L. oil. Renew. Sustain. Energy Rev. 2011, 15, 2240-2251. [CrossRef]

14. Syam, A.M.; Resul, M.F.M.G.; Yunus, R.; Ghazi, T.I.M. Reduction of free fatty acids in crude jatropha curcas oil via an esterification process. Int. J. Eng. Technol. 2008, 5, 92-98.

15. Shah, S.; Gupta, M.N. Lipase catalyzed preparation of biodiesel from Jatropha oil in a solvent free system. Process Biochem. 2007, 42, 409-414. [CrossRef]

16. Jain, S.; Sharma, M.P. Prospects of biodiesel from Jatropha in India: A review. Renew. Sustain. Energy Rev. 2010, 14, 763-771. [CrossRef] 
17. Lu, H.; Liu, Y.; Zhou, H.; Yang, Y.; Chen, M.; Liang, B. Production of biodiesel from Jatropha curcas L. oil. Comput. Chem. Eng. 2009, 33, 1091-1096. [CrossRef]

18. Tiwari, A.K.; Kumar, A.; Raheman, H. Biodiesel production from jatropha oil (Jatropha curcas) with high free fatty acids: An optimized process. Biomass Bioenergy 2007, 31, 569-575. [CrossRef]

19. Berchmans, H.J.; Hirata, S. Biodiesel production from crude Jatropha curcas L. seed oil with a high content of free fatty acids. Bioresour. Technol. 2008, 99, 1716-1721. [CrossRef]

20. Köse, Ö.; Tüter, M.; Aksoy, H.A. Immobilized candida antarctica lipase-catalyzed alcoholysis of cotton seed oil in a solvent-free medium. Bioresour. Technol. 2002, 83, 125-129. [CrossRef]

21. He, C.; Baoxiang, P.; Dezheng, W.; Jinfu, W. Biodiesel production by the transesterification of cottonseed oil by solid acid catalysts. Front. Chem. Eng. China 2007, 1, 11-15.

22. Royon, D.; Daz, M.; Ellenrieder, G.; Locatelli, S. Enzymatic production of biodiesel from cotton seed oil using t-butanol as a solvent. Bioresour. Technol. 2007, 98, 648-653. [CrossRef]

23. Hoda, N. Optimization of biodiesel production from cottonseed oil by transesterification using $\mathrm{NaOH}$ and methanol. Energy Sourcespart A Recoveryutilizationand Environ. Eff. 2010, 32, 434-441. [CrossRef]

24. Azcan, N.; Danisman, A. Alkali catalyzed transesterification of cottonseed oil by microwave irradiation. Fuel 2007, 86, 2639-2644. [CrossRef]

25. Rashid, U.; Anwar, F.; Knothe, G. Evaluation of biodiesel obtained from cottonseed oil. Fuel Process. Technol. 2009, 90, 1157-1163. [CrossRef]

26. Su, C.; Nguyen, H.C.; Pham, U.K.; Nguyen, M.L.; Juan, H.-Y. Biodiesel production from a novel nonedible feedstock, soursop (Annona muricata L.) seed oil. Energies 2018, 11, 2562. [CrossRef]

27. Demirbaş, A. Biodiesel from waste cooking oil via base-catalytic and supercritical methanol transesterification. Energy Convers. Manag. 2009, 50, 923-927. [CrossRef]

28. Zhang, Y.; Dube, M.A.; McLean, D.D.; Kates, M. Biodiesel production from waste cooking oil: Process design and technological assessment. Bioresour. Technol. 2003, 89, 1-16. [CrossRef]

29. Issariyakul, T.; Kulkarni, M.G.; Meher, L.C.; Dalai, A.K.; Bakhshi, N.N. Biodiesel production from mixtures of canola oil and used cooking oil. Chem. Eng. J. 2008, 140, 77-85. [CrossRef]

30. Bobadilla, M.C.; Lorza, R.L.; García, R.E.; Gómez, F.S.; González, E.P.V. An improvement in biodiesel production from waste cooking oil by applying thought multi-response surface methodology using desirability functions. Energies 2017, 10, 130. [CrossRef]

31. Da Cunha, M.E.; Krause, L.C.; Moraes, M.S.A.; Faccini, C.S.; Jacques, R.A.; Almeida, S.R.; Rodrigues, M.R.A.; Caramão, E.B. Beef tallow biodiesel produced in a pilot scale. Fuel Process. Technol. 2009, 90, 570-575. [CrossRef]

32. Chung, K.H.; Kim, J.; Lee, K.Y. Biodiesel production by transesterification of duck tallow with methanol on alkali catalysts. Biomass Bioenergy 2009, 33, 155-158. [CrossRef]

33. Gürü, M.; Artukoğlu, B.D.; Keskin, A.; Koca, A. Biodiesel production from waste animal fat and improvement of its characteristics by synthesized nickel and magnesium additive. Energy Convers. Manag. 2009, 50, 498-502. [CrossRef]

34. Gürü, M.; Koca, A.; Can, Ö.; Cınar, C.; Şahin, F. Biodiesel production from waste chicken fat-based sources and evaluation with $\mathrm{Mg}$ based additive in a diesel engine. Renew. Energy 2010, 35, 637-643. [CrossRef]

35. Tashtoush, G.M.; Al-Widyan, M.I.; Al-Jarrah, M.M. Experimental study on evaluation and optimization of conversion of waste animal fat into biodiesel. Energy Convers. Manag. 2004, 45, 2697-2711. [CrossRef]

36. Öner, C.; Altun, Ş. Biodiesel production from inedible animal tallow and an experimental investigation of its use as alternative fuel in a direct injection diesel engine. Appl. Energy 2009, 86, 2114-2120. [CrossRef]

37. Knothe, G.; Razon, L.F.; Bacani, F.T. Kenaf oil methyl esters. Ind. Crop. Prod. 2013, 49, 568-572. [CrossRef]

38. Lam, M.K.; Lee, K.T. Mixed methanol-ethanol technology to produce greener biodiesel from waste cooking oil: A breakthrough for $\mathrm{SO}_{4} 2-/ \mathrm{SnO}_{2}-\mathrm{SiO}_{2}$ catalyst. Fuel Process. Technol. 2011, 92, 1639-1645. [CrossRef]

39. Paraschivescu, M.C.; Alley, E.G.; French, W.T.; Hernandez, R.; Armbrust, K. Determination of methanol in biodiesel by headspace solid phase microextraction. Bioresour. Technol. 2008, 99, 5901-5905. [CrossRef]

40. Joker, D. Calophyllum inophyllum L. Seed Leaflet; No 87; Forest \& Landscape Denmark: Hørsholm, Denmark, 2004.

41. Anonim. Anonim. Nyamplung Plant-Based Alternative Energy Development Plan 2010-2014. Ministry of Forestry Republic of Indonesia, 2008. Available online: https://anzdoc.com/draft-rencana-aksipengembangan-energi-alternatif-berbasis-t.html (accessed on 30 December 2013). (In Indonesia) 
42. Said, T.; Dutot, M.; Martin, C.; Beaudeux, J.L.; Boucher, C.; Enee, E. Cytoprotective effect against UV-induced DNA damage and oxidative stress: Role of new biological UV filter. Eur. J. Pharm. Sci. 2007, 30, 203-210. [CrossRef]

43. Dweek, A.C.; Meadows, T. Tamanu (Calophyllum inophyllum L.) the Africa, Asia Polynesia \& Pasific Panacea. Int. J. Cosmet. Sci. 2002, 24, 341-348.

44. Kraftiadi, S. Energy Analysis on Nyamplung Oil Making Process; Department of Agricultural Engineering, Faculty of Agriculture, Bogor Agricultural Institute: Bogor, Indonesia, 2011. (In Indonesia)

45. Fathiyah, S. Study Process of Oil Purification Nyamplung as Biofuels; Department of Industrial Technology of Agriculture, Faculty of Agricultural Technology, Bogor Agricultural University: Bogor, Indonesia, 2010. (In Indonesia)

46. Motasemi, F.; Ani, F.N. A review on microwave-assisted production of biodiesel. Renew. Sustain. Energy Rev. 2012, 16, 4719-4733. [CrossRef]

47. Hsiao, M.-C.; Hou, S.-S.; Kuo, J.-Y.; Hsieh, P.-H. Optimized conversion of waste cooking oil to biodiesel using calcium methoxide as catalyst under homogenizer system conditions. Energies 2018, 11, 2622. [CrossRef]

48. Hernando, J.; Letón, P.; Matia, M.; Novella, J.; Alvarez-Builla, J. Biodiesel and FAME synthesis assisted microwave: Homogenous batch and flow process. Fuel 2007, 86, 1644-1646. [CrossRef]

49. Wu, L.; Zhu, H.; Huang, K. Thermal analysis on the process of microwave-assisted biodiesel production. Bioresour. Technol. 2013, 133, 279-284. [CrossRef]

50. Barnard, T.M.; Leadbeater, N.E.; Boucher, M.B.; Stencel, L.M.; Wilhite, B.A. Continuous flow preparation of biodiesel using microwave heating. Energy Fuel 2007, 21, 1777-1781. [CrossRef]

51. Saifuddin, N.; Chua, K.H. Production of ethyl ester (biodiesel) from used frying oil: Optimization of transesterification process using microwave irradiation. Malays. J. Chem. 2004, 6, 77-82.

52. Haryanto, A.; Silviana, U.; Triyono, S.; Prabawa, S. Biodiesel production from transesterification of waste cooking oil with the assistance of micro waves: The effect of power intensity and reaction time on rendement and biodiesel characteristics. Agritech 2015, 35. (In Indonesia)

53. Chen, K.-S.; Lin, Y.-C.; Hsu, K.-H.; Wang, H.-K. Improving biodiesel yields from waste cooking oil by using sodium methoxide and a microwave heating system. Energy 2012, 38, 151-156. [CrossRef]

54. Lertsathapornsuk, V.; Ruangying, P.; Pairintra, R.; Krisnangkura, K. Continuous Transethylation of Vegetable Oils by Microwave Irradiation. In Proceedings of the First Thai Energy Network Academic Conference Ambassador of Jomtien City, Chon Buri, Bangkok, 11-13 May 2005; pp. RE11-1-RE11-4.

55. Sherbiny, S.A.E.; Refaat, A.A.; Sheltawy, S.T.E. Production of biodiesel using the microwave technique. J. Adv. Res. 2010, 1, 309-314. [CrossRef]

56. Anonim. Induction Heating System Topology Review. 2000. Available online: www.fairchildsemi.com (accessed on 5 September 2016).

57. Lucia, O.; Maussion, P.; Dede, E.J.; Burdio, J. Induction heating technology and its applications: Past developments, current technology, and future challenges. Ieee Trans. Ind. Electron. 2013, 6, 2509-2520. [CrossRef]

58. Koertzen, H.W.; Ferreira, J.A.; van Wyk, J.D. A comparative study of single switch induction heating converters using novel component effectivity concepts. In Proceedings of the IEEE Power Electronics Specialists Conference, Toledo, Spain, 29 June-3 July 1992; pp. 298-305.

59. Dede, E.J.; Gonzalez, J.V.; Linares, J.A.; Jordan, J.; Ramirez, D.; Rueda, P. 25-kW/50-kHz generator for induction heating. Ieee Trans. Ind. Electron. 1991, 38, 203-209. [CrossRef]

60. Koertzen, H.W.; Wyk, J.D.V.; Ferreira, J.A. Design of the half-bridge series resonant converters for induction cooking. In Proceedings of the IEEE Power Electronics Specialist Conference Records, Atlanta, GA, USA, 18-22 June 1995; pp. 729-735.

61. Kamli, M.; Yamamoto, S.; Abe, M. A 50-150 kHz half-bridge inverter for induction heating applications. IEEE Trans. Ind. Electron. 1996, 43, 163-172. [CrossRef]

62. Rezon, A. Half Bridge Inverter Design for Induction Heater Power Supply in Plastic Etruder Tool; University of Diponegoro: Semarang, Indonesia, 2013. (In Indonesia)

63. Lozinski, M.G. Industrial Application of Induction Heating; Pergoman Press: London, UK, 1969.

64. Emil, A.; Yaakob, Z.; Kumar, M.S.; Jahim, J.M.; Salimon, J. Comparative evaluation of physicochemical properties of Jatropha seed oil from Malaysia, Indonesia and Thailand. J. Am. Oil Chem. Soc. 2010, 87, 689-695. [CrossRef] 
65. Hsiao, M.-C.; Kuo, J.-Y.; Hsieh, P.-H.; Hou, S.-S. Improving biodiesel conversions from blends of high- and low-acid-value waste cooking oils using sodium methoxide as a catalyst based on a high-speed homogenizer. Energies 2018, 11, 2298. [CrossRef]

66. Huppertz, T. Homogenization of milk other types of homogenizer (high-speed mixing, ultrasonics, microfluidizers, membrane emulsification). Encycl. Dairy Sci. 2011, 761-764.

67. Håkansson, A.; Trägårdh, C.; Bergenståhl, B. Studying the effects of adsorption, recoalescence and fragmentation in a high-pressure homogenizer using a dynamic simulation model. Food Hydrocoll. 2009, 23, 1177-1183. [CrossRef]

68. Ghorbani, A.; Rahimpour, M.R.; Ghasemi, Y.; Raeissi, S. The biodiesel of microalgae as a solution for diesel demand in Iran. Energies 2018, 11, 950. [CrossRef]

69. Hayyan, A.; Alam, M.Z.; Mirghani, M.E.; Kabbashi, N.A.; Hakimi, N.I.N.M.; Siran, Y.M.; Tahiruddin, S. Reduction of high content of free fatty acid in sludge palm oil via acid catalyst for biodiesel production. Fuel Process. Technol. 2011, 92, 920-924. [CrossRef]

70. Çayl, G.; Küsefoglu, S. Increased yields in biodiesel production from used cooking oils by a two-step process: Comparison with one step process by using TGA. Fuel Process. Technol. 2008, 89, 118-122. [CrossRef]

71. Refaat, A.A.; Attia, N.K.; Sibak, H.A.; El Sheltawy, S.T.; ElDiwani, G.I. Production optimization and quality assessment of biodiesel from waste vegetable oil. Int. J. Environ. Sci. Technol. 2008, 5, 75-82. [CrossRef]

72. Dmytryshyn, S.L.; Dalai, A.K.; Chaudhari, S.T.; Mishra, H.K.; Reaney, M.J. Synthesis and characterization of vegetable oil derived esters: Evaluation for their diesel additive properties. Bioresour. Technol. 2004, 92, 55-64. [CrossRef] [PubMed]

73. Vicente, G.; Martinez, M.; Aracil, J. Integrated biodiesel production: A comparison of different homogeneous catalysts systems. Bioresour. Technol. 2004, 92, 297-305. [CrossRef] [PubMed]

74. Özçimen, D.; Yücel, S. Biofuel's Engineering Process Technology; Yıldız Technical University, Bioengineering Department: Istanbul, Turkey, 1969; Volume 742, ISBN 978-953-307-480-1.

75. Kapilan, N.; Baykov, B.D. A review on new methods used for the production of biodiesel. Coal Pet. Coal 2014, $56,62-73$.

76. Sapiuddin, N.; Samiuddin, A.; Kumaran, P. A review on processing for biodiesel production. Trends Appl. Sci. Res. 2015, 10, 1-37. 